\title{
Local production and detection of (specific) IgE in nasal B-cells and plasma cells of allergic rhinitis patients
}

\author{
A. KleinJan, J.G. Vinke, L.W.F.M. Severijnen, W.J. Fokkens
}

\begin{abstract}
Production and detection of (specific) IgE in nasal B-cells and plasma cells of allergic rhinitis patients. A. KleinJan, J.G. Vinke, L.W.F.M. Severijnen, W.J. Fokkens. (C)ERS Journals Ltd 2000.

ABSTRACT: Allergic diseases are characterized by allergic complaints in the shock organ and specific immunoglobulin (Ig)E in serum. Literature data indicate that the nasal mucosa itself could produce at least a large part of the specific IgE in allergic rhinitis patients.

In order to investigate this hypothesis, nasal mucosal biopsies from the inferior turbinate were taken from symptomatic grass pollen allergic rhinitis patients, symptomatic house dust mite allergic rhinitis patients and nonallergic healthy controls, confirmed by radioallergosorbent test and skin-prick test. Immunohistochemical double-staining was performed for B-cells (CD19) with IgE, plasma cells (CD138) with IgE and plasma cells with biotinylated allergens.

Significantly more IgE-positive B-cells and IgE-positive plasma cells were found in the nasal mucosa of allergic patients than in that of nonallergic controls. Double staining with biotinylated allergens and plasma cells showed allergen-positive plasma cells in the nasal mucosa of allergic patients and no allergen-positive plasma cells in the nasal mucosa of nonallergic patients. Blocking experiments using polyclonal antibodies directed against IgE showed a significant reduction in the number of allergenpositive cells in contrast to experiments using polyclonal antibodies directed against IgG, IgA or IgM.

This study describes new evidence that specific immunoglobulin $\mathbf{E}$ is produced locally in the nasal mucosa in patients with seasonal allergic rhinitis and perennial allergic rhinitis, but not in nonallergic controls.
\end{abstract}

Eur Respir J 2000; 15: 491-497.

Dept of Otorhinolaryngology, Erasmus
University Medical Centre Rotterdam, University Medical Centre
Rotterdam, the Netherlands.

Correspondence: A. KleinJan

Dept of Otorhinolaryngology

Erasmus University Rotterdam

Room Eel655

Dr. Molewaterplein 50

3015 GD Rotterdam

The Netherlands

Fax: 31104089441

Keywords: Allergic rhinitis

B-cells

biotinylated allergen

nasal mucosa

plasma cells

specific IgE

Received: May 111999

Accepted after revision December 131999
To date, it has not been known where the production of specific immunoglobulin ( $\mathrm{Ig}) \mathrm{E}$ takes place in allergic rhinitis patients. Some studies have suggested that the nasal mucosa itself is able to produce at least a large part of the IgE [1-5]. HugGins and Brostoff [6] reported patients who had specific IgE in their nasal secretions and no detectable levels of specific IgE in their serum. In addition, specific $\operatorname{IgE}$ is present on cells in the nasal mucosa [7]. The nasal mucosa itself contains all the cell types (dendritic cells, T-cells and B-cells [8] ) and cytokines (interleukin (IL)-4 and IL-13 [9-12]) necessary for an IgE immunoresponse. Other studies have suggested that IgE synthesis takes place in the downstream cervical lymph nodes $[13,14]$ or upper respiratory and lower respiratory lymph nodes [15]. However no information has been obtained as to whether the $\operatorname{IgE}$ comes from the circulation (transudate) or from the mucosal glands (exudatate).

ZuRCHER et al. [16] demonstrated that functional Bcells, isolated from the nose and cultured in a CD40stimulating system, could synthesize IgE. DurHAm et al. [17] reported that local allergen provocation induces $\varepsilon$ germline transcripts in nasal B-cells. They were not able to detect IgE-positive B-cells. PAWANKar et al. [18] suggested novel and critical roles for mast cells obtained from allergic rhinitis patients in amplifying IgE produc- tion, within the local microenvironment of the nasal mucosa.

In this study, the possibility of determining the presence of IgE-positive B-cells, IgE-positive plasma cells and allergen-binding plasma cells in the nasal mucosa of seasonal allergic rhinitis patients, perennial allergic rhinitis patients and nonallergic healthy controls was investigated. Doublestaining experiments were performed to verify whether all allergen-positive cells were also positive for IgE. Blocking experiments using polyclonal antibodies directed against Igs were performed to analyse the specificity of the allergen-binding cells for IgE.

\section{Materials and methods}

\section{Patients and controls}

Nasal biopsy $(2.5 \mathrm{~mm})$ was performed using Gerritsma forceps [19]. Twelve grass pollen allergic rhinitis patients (six male/six female), median age 30 yrs (range 15-45 yrs), with a history of clear seasonal rhinitis for 2 yrs and a skin-prick test with a reaction of $3+$ for grass pollen and a radioallergosorbent test (RAST) score median of 4+ (range $3+-5+$ ) for grass pollen. The biopsy samples from 
the seasonal grass pollen allergic rhinitis patients were taken during the grass pollen season. Sixteen perennial allergic rhinitis patients ( 10 male/six female) median age 25 yrs range $18-51 \mathrm{yrs}$ ) yielded a positive skin-prick test for house dust mite (HDM), 3+, and a RAST score median of $3+$ (range $3+-5+$ ) for Dermatophagoides pteronyssinus. Patients had to have two or more symptoms of perennial rhinitis (nasal blockage, rhinorrhoea, sneezing) and to have required medication for perennial rhinitis for 1 yr. The biopsy samples from the perennial allergic rhinitis patients were taken between October and January (inclusive) during the HDM season. The control biopsy samples were taken from twelve healthy volunteers (seven male/five female), median age 36 yrs (range 18-62 yrs) without nasal complaints or nasal abnormalities on ear, nose and throat examination and a negative RAST.

None of the patients had structural nasal abnormalities, undergone nasal surgery in the past 6 months, acute respiratory or sinus infection, serious or unstable concurrent disease, proven allergy for an other relevant inhalant allergen, undergone treatment with systemic or inhaled/ intranasal corticosteroids or inhaled/intranasal sodium cromoglycate in the preceding month or used astemizole in the previous 6 weeks.

The study was approved by the Ethics Committee. All patients gave informed written consent.

\section{Allergens}

The allergens were covalently bound to a soluble polymer/copolymer matrix labelled with biotin (Diagnostic Products Corporation, Apeldoorn, the Netherlands) [20]. GP1 $\left(50 \mathrm{mg} \cdot \mathrm{mL}^{-1}\right)$, a mixture of biotinylated grass pollen (orchard Kentucky, blue, rye and timothy grasses), and D1 $\left(20 \mathrm{mg} \cdot \mathrm{mL}^{-1}\right)$ biotinylated HDM were used.

\section{Blocking experiment}

In order to determine whether the allergen binding was specific to $\operatorname{IgE}$, cryostat sections were preincubated with blocking polyclonal antibodies directed against $\operatorname{IgA}, \operatorname{IgE}$, $\mathrm{IgG}$, and $\operatorname{IgM}\left(5 \mathrm{mg} \cdot \mathrm{mL}^{-1}\right)$ central laboratory of the Netherlands Red Cross blood transfusion service (CLB), the
Netherlands) and phosphate-buffered saline (PBS, $\mathrm{pH} 7.8$ ), followed by the normal allergen staining procedure. These polyclonal antibodies blocked the cell-bound antibodies of different types. The blocking was based on spheric hindrance or the idiotypes of the antibodies were masked, so that the allergen could not bind. In order to determine the amount of blocking, the number of allergen- positive cells were counted and the signal intensities ranked in a blinded fashion.

\section{Staining procedure}

The antibodies used for the staining procedure are detailed in table 1 . Frozen sections $(6-\mu \mathrm{m}$ thick) were fixed in acetone for $10 \mathrm{~min}$ at room temperature $(22 \pm \mathrm{C})$ and rinsed in PBS ( $\mathrm{pH}$ 7.8). Endogenous peroxidase blocking was carried out by means of treatment for 30 min in $1 \%$ sodium azide and $0.01 \%$ hydrogen peroxide in PBS. The slides were then placed in a semi-automatic stainer (Sequenze; Shandon, Amsterdam, the Netherlands).

\section{Double staining plasma cells or B-cells and immuno- globulin E}

The sections were subsequently incubated for $10 \mathrm{~min}$ with PBS containing bovine serum albumin (BSA, 1\%), normal goat serum $(10 \%)$, and normal rabbit serum $(10 \%)$ (CLB, Amsterdam, the Netherlands) and then for $60 \mathrm{~min}$ with the antibodies to CD138 (plasma cells syndican I; Serotec (Diagnostic Products Corporation, the Netherlands). They were then rinsed with PBS for 5 min, incubated with biotinylated goat antimouse (Biogenix, (Klinipath, Duiven, the Netherlands)) for $30 \mathrm{~min}$, rinsed once more with PBS for $5 \mathrm{~min}$, incubated with alkaline phosphatase-conjugated streptavidin (Biogenix, (Klinipath) for $30 \mathrm{~min}$, rinsed with PBS for $5 \mathrm{~min}$, and incubated for $60 \mathrm{~min}$ with FITCconjugated rabbit antihuman IgE. After rinsing with PBS, they were incubated for $30 \mathrm{~min}$ with peroxidase-conjugated rabbit-anti FITC (Dako (ITK, Uithoorn, the Netherlands)). Finally, the slides were rinsed with PBS and tris-hydroxymethyl-aminomethane (Tris) $(0.2 \mathrm{M}, \mathrm{pH} 8.5)$ for $5 \mathrm{~min}$ each, incubated for $10 \mathrm{~min}$ with $1.0 \mathrm{mM}$ Fast

Table 1. - Antibodies used to stain biopsy specimens

\begin{tabular}{lcl}
\hline Antibody & $\begin{array}{c}\text { Concentration } \\
\mu \mathrm{g} \cdot \mathrm{mL}^{-1} \text { dilution }\end{array}$ & Source \\
\hline Anti CD19 & 1.3 & $\begin{array}{l}\text { Immunotech (Coulter, the Netherlands) } \\
\text { Anti CD138 (plasma cells syndican I) }\end{array}$ \\
FITC-labelled anti-IgE & 1 & Serotec (DPC, Apeldoorn, the Netherlands) \\
Biotinylated grass pollen & 50 & CLB (Amsterdam, the Netherlands) \\
Biotinylated der PI & 20 & DPC \\
Biotinylated goat antimouse & $1: 50$ & DPC \\
Alkaline phosphatase/peroxidase-labelled streptavidine & $1: 50$ & Biogenix (Klini Path, Duiven, the Netherlands) \\
Alkaline phosphatase-labelled goat antibiotin & $1: 50$ & Sigma (the Netherlands) \\
Alkaline phosphatase-labelled streptavidine/biotin complex & $1: 50$ & Vector (Brunschwig Chemie, the Netherlands) \\
Peroxidase-labelled rabbit anti-FITC & $1: 50$ & Dako (ITK, Uithoorn, the Netherlands) \\
Peroxidase-labelled rabbit antimouse peroxidase & $1: 100$ & Sigma \\
Peroxidase-labelled mouse antiperoxidase & $1: 100$ & Sigma \\
\hline
\end{tabular}

IgE: immunoglobulin E; FITC: fluorescein isothiocyanate; DPC: Diagnostic Products Corporation; CLB: central laboratory of the Netherlands Red Cross blood transfusion service. 
Blue substrate, rinsed with sodium acetate $(0.2 \mathrm{M}, \mathrm{pH} 4.6)$ for two periods of $5 \mathrm{~min}$, incubated with 1\% 3-amino-9ethylcarbazole (AEC) for $30 \mathrm{~min}$, rinsed in distilled water and mounted in glycerine/gelatin (1:1).

\section{Double staining immunoglobulin $E$ and biotinylated allergen}

The sections were subsequently incubated for $10 \mathrm{~min}$ with PBS containing BSA $(0.5-1 \%)$, normal rabbit serum $(10 \%)$ and normal goat serum (10\%) (CLB), followed by 100 min with biotinylated allergen (AlaSTAT, DPC) [7] and thereafter for $60 \mathrm{~min}$ with the polyclonal antibodies to IgE. They were then rinsed with PBS for $5 \mathrm{~min}$, incubated with alkaline phosphatase-conjugated goat-antibiotin (Sigma) for 30 min After rinsing with PBS, they were incubated for $30 \mathrm{~min}$ with peroxidase-conjugated rabbit anti-FITC (Dako, (ITK), Uithoorn, the Netherlands). Finally, the samples were rinsed with PBS for 5 min, rinsed with Tris $(0.2 \mathrm{M}, \mathrm{pH} 8.5)$ for $5 \mathrm{~min}$, incubated for $10 \mathrm{~min}$ with $1.0 \mathrm{mM}$ Fast Blue substrate, rinsed with sodium acetate $(0.2 \mathrm{M}, \mathrm{pH} 4.6)$ for two periods of $5 \mathrm{~min}$, incubated with AEC for $30 \mathrm{~min}$, rinsed in distilled water and mounted in glycerine/gelatin $(1: 1)$.

\section{Double staining plasma cells and biotinylated allergen}

The sections were subsequently incubated for $10 \mathrm{~min}$ with PBS containing BSA $(0.5-1 \%)$ and normal rabbit serum (10\%) (CLB), followed by 60 min with the antibodies to plasma cells and thereafter for $100 \mathrm{~min}$ with biotinylated allergen. They were then rinsed with PBS for $5 \mathrm{~min}$, incubated with peroxidase-conjugated Rabbit antimouse (Sigma) for $30 \mathrm{~min}$, rinsed once more with PBS for $5 \mathrm{~min}$ and incubated with peroxidase-conjugated mouse antiperoxidase for $30 \mathrm{~min}$. They were then rinsed with PBS for 5 min, and incubated with alkaline phosphatase-conjugated goat antibiotin (Sigma) for $30 \mathrm{~min}$. Finally, the samples were rinsed with PBS for $5 \mathrm{~min}$, rinsed with Tris buffer $(0.2 \mathrm{M}, \mathrm{pH} 8.5)$ for $5 \mathrm{~min}$, incubated for $10 \mathrm{~min}$ with 1.0 $\mathrm{mM}$ Fast Blue substrate, rinsed with sodium acetate $(0.2$ $\mathrm{M}, \mathrm{pH}$ 4.6) for two periods of $5 \mathrm{~min}$, incubated with AEC for $30 \mathrm{~min}$, rinsed in distilled water and mounted in glycerine/gelatin $(1: 1)$.

\section{Controls}

The controls used were biopsy sections from nonallergic patients and those stained immunohistochemically with irrelevant mouse IgG subclasses. In these sections, no positivity, nonspecific binding of the conjugates or endogenous enzyme activity were found.

\section{Statistical analysis}

The blocking experiments were analysed using the Friedman two-way analysis of variance (ANOVA) test. The distribution of cells in the epithelium and in the lamina propria was not symmetrical and the variances were unequal. For statistical analysis, Kruskal-Wallis one-way ANOVA was used to calculate the overall p-value. A p-value of $<0.05$ was considered to indicate a significant difference between groups of nasal mucosal biopsies. The nonparametric Mann-Whitney U-test was performed to analyse each group with respect to each other.

\section{Results}

Blocking experiment via preincubation with polyclonal antibodies

In nasal mucosal sections from mite allergic patients $(n=6)$ and grass pollen allergic patients $(n=10)$, the number of allergen-positive cells was always lower after preincubation with polyclonal antibodies directed against $\operatorname{IgE}$ $(\mathrm{p}<0.0005$, Friedman two-way ANOVA). The intensity of the signal was also decreased by preincubation with antibodies directed against IgE. No significant effect was seen after preincubation with the other Igs or PBS on the number of allergen-positive cells or the intensity of the specifically stained cells (fig. 1).

\section{Immunohistochemical staining}

Single staining. The number of IgE-positive cells $\cdot \mathrm{mm}^{2}$ section of nasal mucosa is given in table 2 for the epithelium and lamina propria. No IgE-positive cells were observed in the epithelium of healthy control biopsy samples. Significantly (10 fold) more IgE-positive cells were found in the nasal mucosa of allergic patients (grass pollen or mite allergic patients) than in healthy nonallergic control subjects. No differences were observed in the numbers of B-cells (CD19) or CD138-positive cells (plasma cells). Allergen-positive cells were found in allergic patients only, not in controls. GP1-positive cells were only found in patients with only grass pollen allergy. D1-positive cells were only found in the nasal mucosa of patients with perennial allergic rhinitis (allergic to HDM). No allergen-positive cells were found in nonallergic controls.

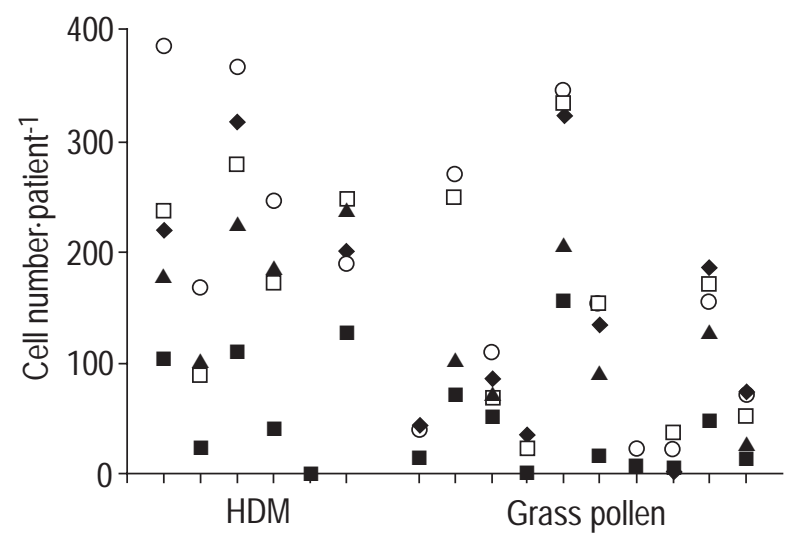

Fig. 1. - Blocking experiments using polyclonal antibodies directed against immunoglobulin (Ig) E ( $(\boldsymbol{Q})$ showed a significant reduction in allergen-positive cells in contrast to those using polyclonal antibodies directed against $\operatorname{IgG}(\square), \operatorname{IgA}(\boldsymbol{\Delta})$ or $\operatorname{IgM}(\diamond)$ and phosphate-buffered saline $(O)$. Biopsy samples from each patient house dust mite (HDM), $\mathrm{n}=6$; grass pollen, $\mathrm{n}=10$ ) are plotted separately. 
Table 2. - Number of cells found in the nasal mucosa of grass pollen allergic patients, perennial allergic patients and healthy controls

\begin{tabular}{|c|c|c|c|c|}
\hline Cell type & Seasonal allergics & Perennial allergics & Controls & ANOVA p-value* \\
\hline \multicolumn{5}{|l|}{ Epithelium } \\
\hline IgE-positive cells & $4(1-41)$ & $14(2-32)$ & $0(0-0)$ & 0.0003 \\
\hline CD19 (B-cells) & $0(0-0)$ & $0(0-6)$ & $0(0-3)$ & 0.2 \\
\hline IgE-positive B-cells & $0(0-1)$ & $0(0-0)$ & $0(0-0)$ & 0.05 \\
\hline \multicolumn{5}{|l|}{ Lamina propria } \\
\hline IgE-positive cells & $417(273-590)$ & $209(97-330)$ & $22(7-37)$ & 0.0001 \\
\hline CD19 (B-cells) & $225(144-293)$ & $152(81-233)$ & $142(114-203)$ & 0.2 \\
\hline Plasma cells & $43(18-100)$ & $78(60-113)$ & $122(46-151)$ & 0.06 \\
\hline Allergen-positive cells & $45(32-85)$ & $30(16-57)$ & $0(0-0)$ & 0.0000 \\
\hline IgE-positive B-cells & $8(4-16)$ & $6(3-13)$ & $1(1-5)$ & 0.02 \\
\hline IgE-positive plasma cells & $8(3-18)$ & $9(6-16)$ & $0(0-6)$ & 0.0007 \\
\hline Allergen-positive plasma cells & $5(3-8)$ & $2(2-7)$ & $0(0-0)$ & 0.0000 \\
\hline
\end{tabular}

*: Kruskal-Wallis one way analysis of variance. Data are presented as median (interquartile range).

Double staining. Immunoglobulin E-positive B-cells. Double staining with polyclonal antibodies directed against $\operatorname{IgE}$ and monoclonal antibodies directed against B-cells resulted in the easy identification of red IgE-positive cells, blue B-cells and mixed-colour (red and blue) IgE-positive Bcells (fig. 2a). In two of the controls, no IgE-positive B-cells were found in the lamina propria. Allergic patients were found to have four times as many IgE-positive B-cells in the lamina propria $(\mathrm{p}<0.02)$ than nonallergic controls. Grass pollen allergic patients had significantly more IgEpositive B-cells in the epithelium $(\mathrm{p}<0.02)$ and in the lamina propria $(\mathrm{p}<0.05)$ than nonallergic controls. Perennial (mite) allergic patients were found to have more IgEpositive B-cells $(\mathrm{p}<0.05)$ in the lamina propria than nonallergic controls. No significant differences were observed between hay fever patients and perennial mite allergic patients (fig. 3a).

Immunoglobulin E-positive plasma cells. Double staining with polyclonal antibodies directed against IgE and monoclonal antibodies directed against plasma cells resulted in the easy identification of red IgE-positive cells, blue plasma cells and mixed-colour (red and blue) IgE-positive plasma cells (fig. 2b). Plasma cells were only evaluated in the lamina propria because CD138 is also expressed weakly in epithelial cells (fig. 2b). Cells positive for $\operatorname{IgE}$ alone, IgE-positive plasma cells and non-IgE-positive plasma cells were found in allergic patients as well as in nonallergic controls. However, in seven of the controls, no IgE-positive plasma cells were found. In the lamina propria of the nasal mucosal biopsies from allergic patients, significantly eight-fold $(\mathrm{p}<0.0007)$ more IgE-positive plasma cells were present than in biopsy samples from nonallergic controls (fig. $3 b$ ).

Immunoglobulin E-positive allergen positive cells. IgEpositive cells stained red, the allergen-positive IgE-positive cells stained mixed red/blue and hardly any cells positive for allergen alone (blue, if present) were found. All allergen-positive cells were also positive for IgE, except in one of the grass pollen allergic patients (median $100 \%$ (range $71-100 \%$ ) and one of the mite allergic patients (median $100 \%$ (range 96-100\%)).

Allergen positive plasma cells. Double staining was performed using biotinylated allergens (blue) and antibodies a)

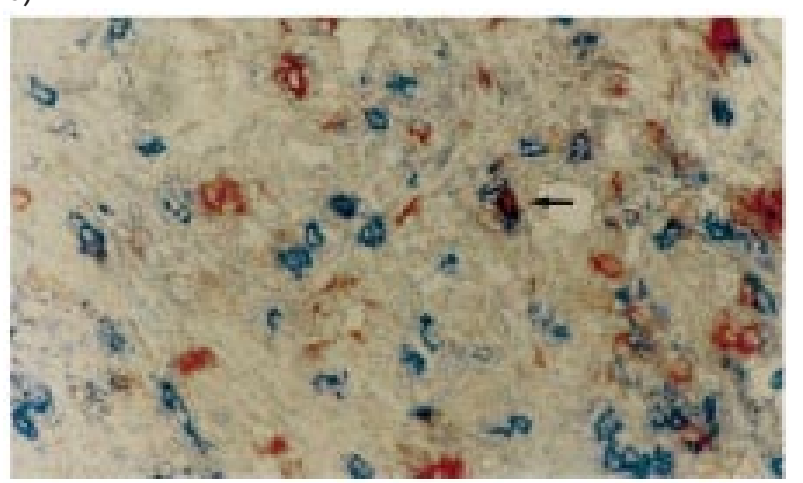

b)

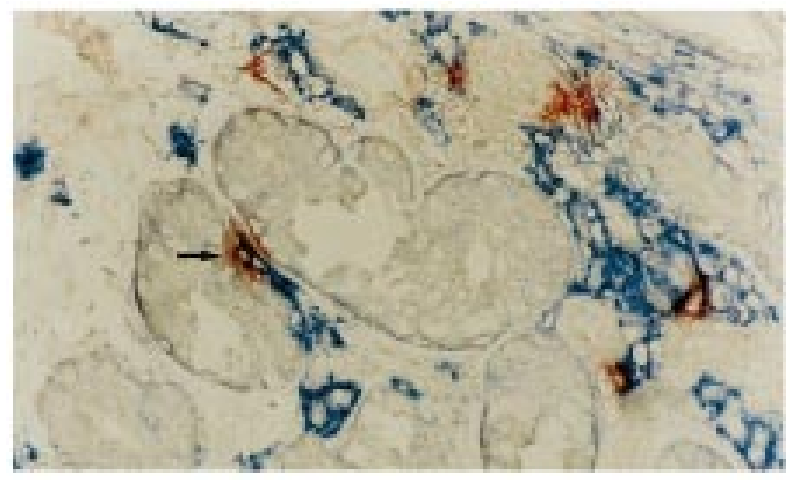

c)

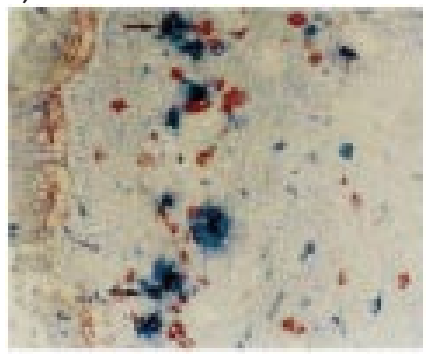

d)

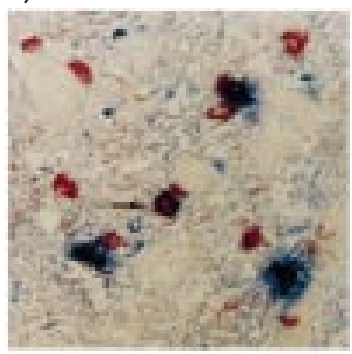

Fig. 2. - Photomicrographs of four nasal mucosal biopsy sections obtained from allergic patients, and double stained immunohistochemically with antibodies directed against immunoglobulin (Ig) E (red) and: a) B-cells (blue) (arrows indicate IgE-positive B-cells) and ; b) plasma cells (blue) (arrows indicate IgE-positive plasma cells); and c, d) double staining using biotinylated allergens (blue) and antibodies directed against plasma cells (red) (arrows indicate allergen-positive plasma cells). (Internal scale bars $=36 \mu \mathrm{m}(\mathrm{a}-\mathrm{c}) ; 72 \mu \mathrm{m}(\mathrm{d})$.) 

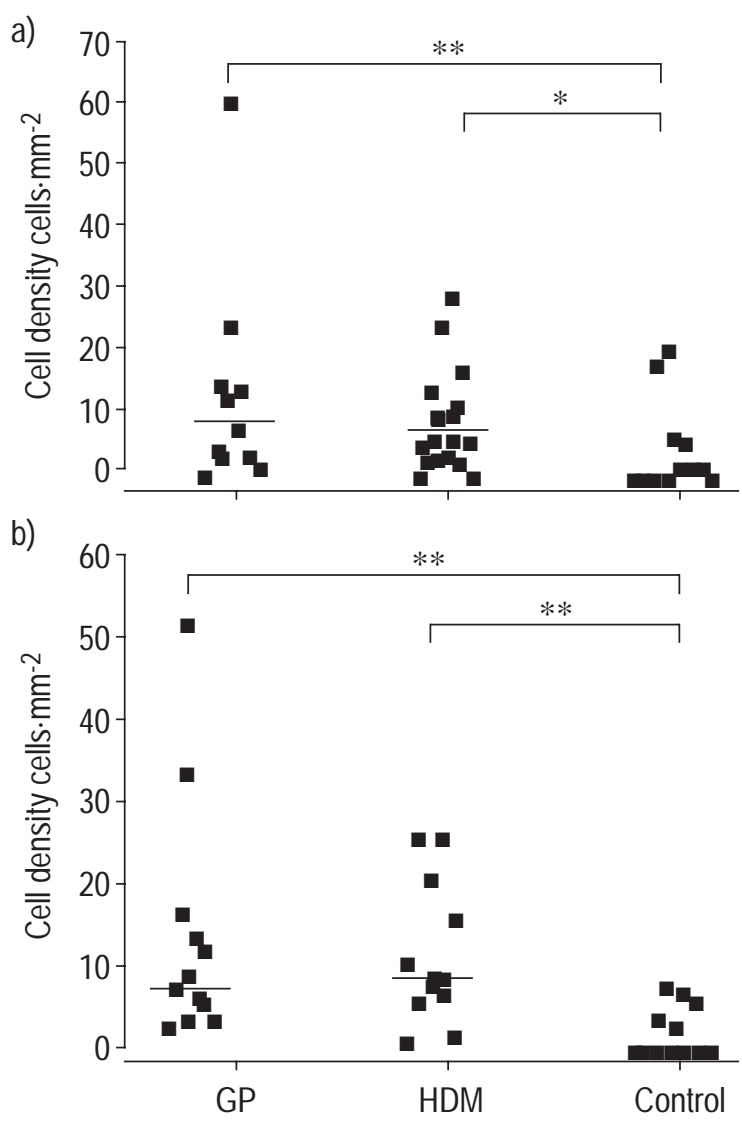

Fig. 3. - Density of: a) immunoglobulin (Ig) E-positive B-cells; and b) IgE-positive plasma cells in the nasal mucosa (lamina propria) of grass pollen allergic patients (GP, $n=11$ ), perennial allergic patients (HDM; a) $\mathrm{n}=16, \mathrm{~b}) \mathrm{n}=12)$ and healthy controls $(\mathrm{n}=12)$. $* \mathrm{p}<0.05 ; * *: \mathrm{p}<0.01$.

directed against plasma cells red. The allergen-positive cells generally showed a membrane-staining pattern, with the allergen bound on the surface of the cell. However, another staining pattern was found for the allergen-positive plasma cells, which also showed blue staining in and around the cell (fig. 2c). This pattern of staining was observed in all grass pollen allergic patients. However, in two of the mite allergic patients, no allergen-positive plasma cells were found.

\section{Discussion}

Local production of specific IgE in the nasal mucosa has been hypothesized by several authors [1-5]. Durham et al. [21] recently described the expression of $\varepsilon$ germ line gene transcripts indicating isotype-switching B-cells and an increase in the level of messenger ribonucleic acid (mRNA) encoding the heavy chain of $\mathrm{IgE}$ in nasal B-cells in the nasal mucosa after local allergen provocation. ZURCHER et al. [16] demonstrated the possibility of $\operatorname{IgE}$ synthesis by nasal epithelial B-cells; functional B-cells can be isolated from the nose, and, after stimulation with IL-4 and antibodies directed against CD40, IgE-protein synthesis could be induced. DiAZ-SANCHEZ et al. [22] also found IgE-producing B-cells and mRNA encoding $\operatorname{IgE}$ in nasal lavages fluid from allergic rhinitis patients.
In this biopsy study, the production of $\operatorname{IgE}$ by B-cells and plasma cells in vivo was evaluated in naturally provoked allergic rhinitis patients. This study showed significantly more IgE-positive B-cells and IgE-positive plasma cells in allergic patients than in nonallergic controls. IgEpositive B-cells and plasma cells were also observed in healthy controls. An explanation for these IgE-positive cells could be the smoking of some of the patients, (environmental) tobacco smoke increases the number of IgE-positive cells [23, 24]. The allergen-positive plasma cells (specific IgE) were observed only in allergic patients, in accordance with previous observations of allergen-positive cells occurring only in the nasal mucosa of allergic rhinitis patient and not in nonallergic controls [7]. The observation of the presence of allergen-positive plasma cells and the finding that all allergen-positive cells were also IgE-positive indicate that the local production of allergen-specific IgE takes place in the nasal mucosa. Blocking experiments showed that the binding was specific for $\operatorname{IgE}$ but not for $\operatorname{IgG}, \operatorname{Ig}$ A or IgM, meaning that specific IgE is the critical factor for allergen binding to cells and that this binding was not based on the allergen binding to $\operatorname{IgG}$, IgA or IgM. IgE antibodies remain firmly fixed to mast cells for an extended period. IgA antibodies function by inhibiting the adherence of coated microorganisms to the surface of mucosal cells, thereby preventing entry into the body tissues. IgG has properties with respect to the neutralization of bacterial toxins and binding to microorganisms to enhance their phagocytosis. The locally-produced IgA or IgG levels were not high enough to neutralize the allergen binding to specific IgEpositive cells.

In a previous study, it was observed that monoclonal antibodies directed against $\operatorname{IgE}$ recognize $>80 \%$ of all allergen-positive cells [7]; the present study used rabbit polyclonal antibodies directed against IgE, and showed that all allergen-positive cells were also IgE-positive. The significantly higher number of IgE-positive B-cells in the nasal mucosa of allergic patients compared to the nasal mucosa of nonallergic controls and the observation of no difference in numbers of B-cells expressing CD40 (data not shown) are an indication that, the $\varepsilon$ germ line switches to IgE-positive B-cell early in life. These switched B-cells require only IL-4 to respond with persistent $\mathrm{IgE}$ formation [25]. The significantly higher numbers of IgE-positive plasma cells in the allergic nasal mucosa compared to the controls suggests that the maturation of IgE-positive Bcells to IgE-producing plasma cells takes place locally in the nasal mucosa. B-cells express CD 40 during the mature/activated stage [26]. It is not possible to differentiate between IgE-positive B-cells if they are IgE-positive memory B-cells or at least activated B-cells [27]. Once formed, the switched IgE-positive memory B-cells are long-lived cells, but not all IgE responses lead to the formation of IgE-positive memory B-cells [28]. The present data suggest that the maturation of IgE-expressing Bcells (activated or memory) to IgE-producing plasma cells takes places in the nose. It is noteworthy that many of the cytokines induced by allergen provocation such as IL-4, IL-6 and IL-13 are also B-cell proliferation factors [11, $12,29]$. The nasal mucosa might also be the place of maturation of B-cells. In the nasal mucosa are germinal centres containing dendritic cells, T-cells and B-cells. The availability of IL-4 and IL-13 produced in the nasal 
mucosa makes it possible for isotype switching of B-cells to IgE-positive B-cells and proliferation and maturation of B-cells to IgE-producing plasma cells to occur. Moreover, recent work done by the group of DURHAM et al. [17] reports an increase in the number of B-cells expressing $\varepsilon$ germ line transcripts locally in the nasal mucosa of hay fever patients after allergen provocation. This increase in $\varepsilon$ germ line transcripts could be suppressed by local steroid treatment. Similar observations of isotype switching have been made by SAXON et al. [22] in nasal mucosal cells. Not only T-cells but also mast cells and basophils have the capacity to stimulate IgE synthesis by B-cells, as producers of IL-4 and IL-13 and by the interaction of mast cells CD154 (CD40 ligand) with B-cell CD40 [18, $30,31]$. The mast cell/basophilic induction and stimulation of B-cell IgE-production indicate that immunoglobulin switching, previously thought to take place only in lymph node germinal centres, may also occur in peripheral organs such as the nose. However, it is not clear what impact this mast cell/B-cell interaction has on the amount of IgE produced.

Comparing the present upper airway results with data from the lower airways, CHVAтснко et al. [32] describe antigen-driven differentiation of B-cells via induction of a follicular dendritic cell network in mice, with germinal centres occurring in the parenchyma of inflamed lungs. These germinal centres would then provide a local source of immunoglobulin E-secreting plasma cells, contributing to the release of factors mediating inflammatory processes in the lung [32]. Transplantation literature case reports describe nonasthmatic recipients of asthmatic lungs who develop asthma after transplantation; however, asthmatic recipients of normal lungs do not develop asthma for up to 3 yrs after transplantation. This supports the local characteristic of lung disease in asthma, [33]. It is unclear which portion of specific immunoglobulin $\mathrm{E}$ is produced in the nasal mucosa of allergic rhinitis patients because lymphoid tissues may also be involved in the production of immunoglobulin E [4, 15, 34]. However, this study clearly demonstrates that B-cells/plasma cells in the nasal mucosa of allergic rhinitis patients produce (specific) immunoglobulin E. This concurs with the hypothesis put forward in the 1970s $[1-3,6]$.

Acknowledgements. The authors thank Diagnost Products Corporation Netherlands (Apeldoorn, the Netherlands) for supplying the biotinylated allergens and S.P. Thomas for textual advice.

\section{References}

1. Merrett TG, Houri M, Mayer AL, Merrett J. Measurement of specific IgE antibodies in nasal secretion-evidence for local production. Clin Allergy 1976; 6: 69-73.

2. Mygind N, Weeke B. Local IgE antibodies in nasal secretion. Lancet 1975; ii: 502.

3. Platts-Mills TA. Local production of $\operatorname{IgG}, \operatorname{IgA}$ and $\operatorname{IgE}$ antibodies in grass pollen hay fever. J Immunol 1979; 122: 2218-2225.

4. Ali M, Mesa-Tejada R, Fayemi AO, Nalebuff DJ, Connell JT. Localization of IgE in tissues by an immunoperoxidase technique. Arch Pathol Lab Med 1979; 103: 274 275.

5. Brandtzaeg P, Jahnsen FL, Farstad IN. Immune functions and immunopathology of the mucosa of the upper respiratory pathways. Acta Otolaryngol (Stockh) 1996; 116: 149-159.

6. Huggins KG, Brostoff J. Local production of specific IgE antibodies in allergic-rhinitis patients with negative skin tests. Lancet 1975; 2: 148-150.

7. KleinJan A, Godthelp $\mathrm{T}$, van Toornenenbergen AW, Fokkens WJ. Allergen binding to specific IgE in the nasal mucosa of allergic patients. J Allergy Clin Immunol 1997; 99: 515-521.

8. Fokkens WJ, Holm AF, Rijntjes E, Mulder PG, Vroom TM. Characterization and quantification of cellular infiltrates in nasal mucosa of patients with grass pollen allergy, non-allergic patients with nasal polyps and controls. Int Arch Allergy Appl Immunol 1990; 93: 66-72.

9. Ghaffar O, Laberge S, Jacobson MR, et al. IL-13 mRNA and immunoreactivity in allergen-induced rhinitis: comparison with IL-4 expression and modulation by topical glucocorticoid therapy. Am J Respir Cell Mol Biol 1997; 17: 17-24.

10. Bradding $\mathrm{P}$, Feather IH, Wilson $\mathrm{S}$, et al. Immunolocalization of cytokines in the nasal mucosa of normal and perennial rhinitic subjects. The mast cell as a source of IL4, IL-5, and IL-6 in human allergic mucosal inflammation. J Immunol 1993; 151: 3853-3865.

11. Durham SR, Ying S, Varney VA, et al. Cytokine messenger RNA expression for IL-3, IL-4, IL-5, and granulocyte/ macrophage-colony-stimulating factor in the nasal mucosa after local allergen provocation: relationship to tissue eosinophilia. J Immunol 1992; 148: 2390-2394.

12. KleinJan A, Dijkstra MD, Boks SS, Severijnen LAM, Mulder PGH, Fokkens WJ. Increase in IL-8, IL-10, IL-13 and RANTES mRNA levels (in situ hybridization) in the nasal mucosa after nasal allergen provocation. $J$ Allergy Clin Immunol 1999; 103: 441-450.

13. Ganzer U, Bachert C. Localization of IgE synthesis in immediate-type allergy of the upper respiratory tract. ORL J Otorhinolaryngol Relat Spec 1988; 50: 257-264.

14. Gillon J. Where do mucosal mast cells acquire IgE? Immunology Today 1981; 2: 80-81.

15. McMenamin C, Girn B, Holt PG. The distribution of IgE plasma cells in lymphoid and nonlymphoid tissues of high-IgE responder rats: differential localization of antigen-specific and "bystander" components of the IgE response to inhaled antigen. Immunology 1992; 77: 592-596.

16. Zurcher AW, Derer T, Lang AB, Stadler BM. Culture and IgE synthesis of nasal B cells. Int Arch Allergy Immunol 1996; 111: 77-82.

17. Durham SR, Gould HJ, Thienes CP, et al. Expression of epsilon germ-line gene transcripts and mRNA for the epsilon heavy chain of IgE in nasal B cells and the effects of topical corticosteroid. Eur J Immunol 1997; 27: 2899 2906.

18. Pawankar R, Okuda M, Yssel H, Okumura K, Ra C. Nasal mast cells in perennial allergic rhinitics exhibit increased expression of the Fc epsilonRI, CD40L, IL-4, and IL-13, and can induce IgE synthesis in B cells. J Clin Invest 1997; 99: 1492-1499.

19. Fokkens WJ, Vroom TM, Gerritsma V, Rijntjes E. A biopsy method to obtain high quality specimens of nasal mucosa. Rhinology 1988; 26: 293-295.

20. Said El Shami A, Alaba O. Liquid-phase in vitro Allergenspecific IgE Assay with in situ immobilization. In: Said El Shami A, Merrett TG, editors. Allergy and Molecular Biology. 74th Edn. Oxford, New York, Pergamon Press, 1989; pp. 191-201.

21. Durham SR, Gould HJ, Hamid QA. Local IgE production 
in nasal allergy. Int Arch Allergy Immunol 1997; 113: 128-13.

22. Diaz-Sanchez D, Tsien A, Fleming J, Saxon A. Combined diesel exhaust particulate and ragweed allergen challenge markedly enhances human in vivo nasal ragweed-specific IgE and skews cytokine production to a T helper cell 2type pattern. J Immunol 1997; 158: 2406-2413.

23. Vinke JG, KleinJan A, Severijnen LAWFM, Fokkens WJ. Passive smoking causes an "allergic" cell infiltrate in the nasal mucosa of non-atopic children. Int $J$ Pediatr Otorhinolaryngol 1999; 51: 73-81.

24. Bouwhuijsen ECA, Dijkstra MD, Severijnen EAWFM, KleinJan A, Fokkens WJ. Effects of cigarette smoking on nasal mucosa inflammation. Allergologie 1996; 19: 56.

25. Savelkoul HF, van Ommen R. Role of IL-4 in persistent IgE formation. Eur Respir J 1996; 22: Suppl. 22, 67s$71 \mathrm{~s}$.

26. Zola H. The surface antigens of human B lymphocytes. Immunology Today 1987; 8: 308-315.

27. Abbas AK, Lichtman AH, Pober JS. Cellular and Molecular Immunology. 3th edn. London, 1997.

28. Le Gros G, Schultze N, Walti S, et al. The development of
$\operatorname{IgE}+$ memory $\mathrm{B}$ cells following primary $\operatorname{IgE}$ immune responses. Eur J Immunol 1996; 26: 3042-3047.

29. Cocks BG, de Waal Malefyt R, Galizzi JP, de Vries JE, Aversa G. IL-13 induces proliferation and differentiation of human B cells activated by the CD40 ligand. Int Immunol 1993; 5: 657-663.

30. Gauchat JF, Henchoz S, Mazzei G, et al. Induction of human $\operatorname{IgE}$ synthesis in B cells by mast cells and basophils. Nature 1993; 365: 340-343.

31. Yanagihara Y, Kajiwara K, Basaki Y, Ikizawa K, Akiyama K, Saito H. Induction of human IgE synthesis in B cells by a basophilic cell line, KU812. Clin Exp Immunol 1997; 108: 295-301.

32. Chvatchko Y, Kosco-Vilbois MH, Herren S, Lefort J, Bonnefoy JY. Germinal center formation and local immunoglobulin $\mathrm{E}$ ( $\mathrm{IgE}$ ) production in the lung after an airway antigenic challenge. $J$ Exp Med 1996; 184: 23532360.

33. Corris PA, Dark JH. Aetiology of asthma: lessons from lung transplantation. Lancet 1993; 341: 1369-1371.

34. Drake-Lee AB, Barker TH. Free and cell bound IgE in nasal polyps. J Laryngol Otol 1984; 98: 795-801. 